\title{
Pocahontas' Baptism: Reformed Theology and the Paradox of Desire ${ }^{\mathrm{i}}$
}

Let therefore this my well advised protestation, which here I make betweene God and my own conscience, be a sufficient witnesse, at the dreadful day of judgement (when the secret of all mens harts shall be opened) to condemne me herein, if my chiefest intent and purpose be not, to strive with all my matter, no way led (so farre forth as mans weaknesse may permit) with the unbridled desire of carnall affection: but for the good of this plantation, the honour of our countrie, for the glory of God, for my owne salvation, and for the converting to the true knowledge of God and Jesus Christ, an unbeleeving creature, namely Pokahuntas.ii

John Rolfe's letter detailing his internal struggles concerning his relationship with his future wife Pocahontas brings into play many of the issues that are central to Reformed ideas - conscience, judgement, salvation and desire. The struggle between flesh and faith, desire and salvation which Rolfe presents fits our understanding of Calvinist thought to the extent that Peter Hulme has called the letter a 'classic Puritan document'.iii Rolfe's denial of 'the unbridled desire of carnall affection' seems archetypal in its renunciation of the flesh, but there also is another form of desire at work in Rolfe's letter. Where he denies that his yearning is carnal he celebrates his longing to convert the native. This is very different, but the recognition of the link between the two desires for the flesh and the spirit is necessary if we are to truly understand the Reformed theology which travelled across the Atlantic in the early seventeenth century.

Reformed thought, paradoxically it would seem, produces, refuses and relies upon desire and in this essay I will trace the ways in which these very different longings operate in John Rolfe's letter and in the baptismal theology which informs the conversion of Pocahontas. In examining the desires of the convertor and in recognising the link between the feared yearning for the flesh and the sacred desire for the divine an important understanding of Reformed thought can be traced. I begin with an account of some of the basic principles of Reformed theology and then look specifically at Rolfe's struggle and the baptism of Pocahontas. In this narrative of conversion can be found both the terrors and joys of Calvinist 
thought.

The design of the universe proposed in Reformed thought had important implications for humanity. John Calvin's understanding was straightforward: 'All future events being uncertain to us, seem in suspense as if ready to take either direction'; they seem to be, but this is a misperception because in reality 'nothing will happen which the Lord has not provided'.iv Calvin's God was not a creator who 'completed his work once and for all, and then left it.'(I, 171) He was 'by a special Providence sustaining, cherishing, superintending, all the things which he has made, to the very minutest, even to a sparrow.' (I, 172)v This belief in the providential design of the universe was taken up by many in England. Thomas Morton wrote that God's 'permission is not idle, but effectuall and working: for God is not an idle looker on, as if he had cast off the care of the world and of his creatures, and left all at sixe and seauen (as we vse to speake) but he hath a parte in this worke.'vi

In records of the Virginia Colony itself a similar sense of the unquestioned faith in providence emerges which offers an insight into the early modern understanding of God's work in the universe. vii The 1609 sailing of the settlers was fraught with difficulties: one of the ships was separated from the rest and assumed lost. However, this vessel, which carried Sir Thomas Gates, the Governor, and Sir George Somers, the Admiral of Virginia, had landed in Bermuda and eventually arrived in Jamestown just as the other settlers had decided to abandon the weak and failing colony. The meeting of the two groups - the disillusioned settlers and the 'lost' voyagers - was not understood as a chance occurrence but as evidence of the workings of God: accidents were perceived to be impossible within Reformed beliefs which so emphasised God's 'effectuall' presence. Calvin cited Basilius Magnus' 'true saying' that 'Fortune and Chance are heathen terms; the meaning of which ought not to occupy pious minds.' (I, 179) His emphasis on providence can be traced back to Augustine's belief that there is no point in worshipping the goddess Fortuna because if she is fortune (i.e. luck) there is no advantage in worshipping her. If she discriminates in favour of her worshippers she is not fortune.'viii Following Calvin and Augustine Alexander Whitaker, the preacher of Henrico in Virginia, called the return of the lost ship carrying the colonists evidence of 
the 'speciall and most fatherly prouidence of God'.ix Ultimately the denial of chance and the belief in the providential design of the universe underlined the sense that the organisation of the world was God's work not humans' and the moment of the reappearance of the lost ship, when despair was turned into joy, was read as evidence of divine support for the colonial endeavour.

So the providential design of the universe which Calvin proposed reflected a sense of the constant presence of God in the life of humanity, but it was not only the providential order of events which was important in Reformed thought. The doctrine of predestination operated on a more personal level. Where providentialism looked to the universe as a whole predestinarianism concentrated on the place of the individual Christian and instead of the power to choose which was offered in Pelagian ideas Reformed thinkers proposed absolute powerlessness for humanity. ${ }^{x}$ Calvin and Reformed theologians such as William Perkins proclaimed a new vision of humanity. Perkins, 'the most widely-read and influential puritan theologian' of his age, xi wrote that 'All men are wholly corrupted with sin through Adams fall, and so are become slaues of Satan and guilty of eternall damnation.'xii This understanding of the inherently sinful nature of humanity is repeated in English Reformed writings throughout the late sixteenth and early seventeenth century. In his 'best-seller', The Plaine Mans Path-way to Heaven, Arthur Dent has Philagathus say to Theologus 'You speake, as if a man could doo no other but sinne'. xiii Sixteen years later John Moore wrote 'So that man now of his owne nature is no lesse the bondslave of $\sin$, then the slaves which are bought, whose Masters use their service, as that of their Oxen and Asses, at their pleasure.'xiv The Reformed human, like the beast, lacked dignity just as he lacked, on his own, immortality. To be immortal was a gift from God; predetermined, not dependent upon human effort or work. The power to enact salvation for the self - the Pelagian position - had gone, and what remained was the Augustinian position: the powerless human.

The other side of predestination, of course, was that the elect were born to salvation and that there was nothing which a person who had received election (entry into eternal life) could do to alter this fact. All worldly actions, it would seem, were meaningless. Indeed, in his 1610 sermon read before the new Governor of the Virginia colony, William Crashaw placed particular emphasis on this issue. In answer to the question 'If we be sure we cannot fall from Gods fauour, then what needs a man care how he 
liues?', Crashaw answered

no man can iustly take occasion thus to abuse this doctrine, for the vngodly and vnsanctified man was neuer yet in the state of grace, therefore to him this doctrine pertaines not: and for him that is sanctified and in Gods fauour this resolution cannot befall him: which appeares most euident, both in reason and religion. ${ }^{\mathrm{xv}}$

The belief in predestination was proof, it would seem, of salvation. To doubt the theory, to question the implications of the absolute power of God, was to reveal oneself to be among the reprobate. The link Crashaw made between belief in this central principle and salvation was, according to H.C. Porter, reiterated throughout Reformed English culture: 'the only pastoral answer to the problem [of predestination] was to assume that all pious hearers of the word were elected; however Calvinist in the study, the preacher must be Arminian in the pulpit'. xvi Belief in Reformed dogma was evidence of the possession of grace which was itself proof of election. This sense of faith underlying all doubts is what, perhaps, makes Rolfe's letter such an archetypal document and a close reading of this text reveals in greater detail the workings of Reformed belief in early modern culture.

In his letter to Sir Thomas Dale John Rolfe presents his anxieties about his relationship with the native woman, Pocahontas. His fears are based in reality: in 1609, in a sermon given before members of the Virginia Company, William Symonds aligned the English settlers with the Jews and proposed that 'Abrams posteritie [must] keep them to themselues. They may not marry nor giue in marriage to the heathen, that are uncircumcised.'xvii The colonist and the native it would seem were understood as distinct races, different beings altogether. Miscegenation, the sexual congress of the two groups, was outlawed.

Rolfe himself concurred with Symonds and cited scriptural precedent for the separation of the races (in Rolfe's case God's 'heavie displeasure' with 'the sonnes of Levie and Israel for marrying strange wives' (241)). But, for Rolfe the important phrase in Symonds' sermon was 'that are uncircumcised'. In converting Pocahontas he could avoid accusations of 
miscegenation because the converted native became equal following the Christian belief in monogenesis (shared origins). Miscegenation could only exist if there was a sense of difference and this sense was impossible if there was a declaration, as there was in discussions of conversion, of the possibility of shared faith and the shared paternity of Christ.xviii

Underlying this emphasis on conversion, however, were the dangers produced by the understanding of miscegenation which it seemed to deny. If Rolfe, who, according to Raphe Hamor 'had bin in loue with Pocahuntas and she with him', could convert Pocahontas he could continue his relationship with her.xix The desire to convert and the desire for Pocahontas become entwined and this is where Rolfe's fears lie. Is he only desiring to convert Pocahontas so that he can fulfil his fleshy, forbidden desires thus revealing himself to be always-already reprobate? The 'dangerous combate' in his soul, the fearful need to 'finde any fit wholesome and apt applications to cure so dangerous an ulcer' (241) lead Rolfe within to the study of his own motives. The Reformed sense of the fragility of humanity is his conventional starting point:

I forgot not to set before mine eies the frailty of mankinde, his prones to evill, his indulgencie of wicked thoughts, with many other imperfections wherein man is daily insnared, and oftentimes overthrowne, and them compared to my present estate. (241)

He continues, examining the truth of his feelings towards Pocahontas, and records

I have ended my private controversie with this: surely these are wicked instigations, hatched by him who seeketh and delighteth in mans destruction; and so with fervent praiers to be ever preserved from such diabolical assaults (as I tooke those to be) I have taken some rest. (241)

This image of desperation and terror fulfils many of our ideas about the Reformed temperament. Powerless to change God's will following the change from a Pelagian to an Augustinian understanding of the universe Reformed Christians believed that salvation or reprobation was not in their own hands but was already decided by God: that their function was 'not to choose but to be chosen.'xx There was no sense of man as deserving of salvation in Reformed theology, quite the opposite: Calvin wrote that 'when men are 
judged by their natural endowments, not an iota of good will be found from the crown of the head to the sole of the foot'. (II, 74) What was worthy in the individual was placed there by God.

This would seem to be the logic behind Rolfe's fears but ultimately the letter does not leave the reader with an image of Rolfe continuing in the many passions and sufferings which I have daily, hourely, yea and in my sleepe indured' (242). Rather the letter starts and concludes with an assertion of his status as true believer. It begins 'When your leasure shall best serve you to peruse these lines, I trust in God, the beginning will not strike you into a greater admiration, then the end will give you good content.' (239) It ends with a declaration of hope: 'I will never cease, (God assisting me) untill I have accomplished, and brought to perfection so holy a worke [Pocahontas' conversion], in which I will daily pray God to blesse me, to mine, and her eternall happines.' (244) Somewhere in the middle of the letter Rolfe has found assurance that his desires are from God and not the devil. The record of his sufferings reveals not his sinfulness but his unquestionable innocence which is based in his 'unspotted conscience' (239). It is through an examination of the workings of conscience that the logic of Rolfe's assurance can be found.

III

In The Discourse of Conscience (1596) William Perkins proposed that the conscience is 'a part of the vnderstanding in al reasonable creatures' which reveals the invisible workings of God: the true believer looks not for external symbols of salvation, but for internal proofs. (I, 517) It is not only a poetic technique which made Sir Philip Sidney's muse advise him to "look in thy heart, and write"', it is a product of Protestantism: the truth lies within the individual Christian, not outside of him/her in the symbols of the external world.. $\mathrm{xi}$

Perkins' model of the Christian understanding is a tripartite structure of mind, memory and conscience. The mind is the 'storehouse and keeper of all manner of rules and principles'; memory 'serues to bring to minde the particular actions which a man hath done or not done'. It is the role of conscience to 'determine' of these actions. (I, 535) The conscience acts like an internal replacement of the Catholic priest: it is, Perkins wrote, 'a thing placed of God in the middest betweene him and man, as an arbitratour to giue sentence and to pronounce either with man or against man vnto 
God'.(I, 517) It is the place where the Christian can find assurance of salvation.

The tripartite structure of the human understanding is mirrored in the tripartite structure of the practical syllogism (or reflex actxxii) which is used to illustrate faith:

Every one that beleeues is the childe of God:

But I doe beleeue:

Therefore I am the child of God. (I, 547)

The first part is an act of mind - a general principle; the second part calls in memory - a personal and particular understanding; and the third part is a judgement which brings the first two together. Perkins links immortality the existence of grace - with reason. The ability to syllogise represents the true exercise of the conscience, and the conscience itself can be seen as proof of God's grace in the Christian.

This is the basis of John Rolfe's examination of his actions concerning Pocahontas. Even while he asks himself if he is being tempted by the devil he is exercising his understanding. Taking Perkins' tripartite structure as his foundation Rolfe reveals the working of mind, memory and conscience in his performance of the practical syllogism. The general principle which motivates Rolfe is revealed in his answer to the question the holy spirit of God hath often demaunded of me, why was I created?'

If not for transitory pleasures and worldly vanities, but to labour in the Lords vineyard, there to sow and plant, to nourish and increase the fruites thereof, daily adding with the good husband in the Gospell, somewhat to the tallent, that in the end the fruites may be reaped, to the comfort of the laborer in this life, and his salvation in the world to come? (242)

The next part of Rolfe's syllogism comes in his recollection of his own relationship with Pocahontas, and finally these two are brought together in the completion of the trinity of thoughts through the act of conscience. 'What should I doe? shall I be of so untoward a disposition, as to refuse to lead the blind into the right way?' (242). In short Rolfe's syllogism looks something like this: 
It is a Christian duty to labour for God.

I am working for God in converting Pocahontas.

Therefore I am performing my Christian duty.

By looking within, calling on the workings of his conscience, Rolfe is able to assuage his fears. The desire which is fleshy and which terrifies Rolfe is a pure desire which co-exists with the desire to convert. The fleshiness of the longing in fact proves the innocence of the desire in that it forces Rolfe to interrogate himself and to find true fear which is evidence of the working of the conscience. Perkins wrote in that you are grieued with a godly sorrow for your sins, it is a good token of the grace of God in you'. (I, 383) In this sense Rolfe's fear is evidence of his salvation, if he was not saved he would not question his status. Paradoxically he needs the fleshy desire in order to access the spiritual truth.

Reformed ideas produce the struggle and the reassurance which are voiced in Rolfe's letter. In fact, the two are inseparable. To have reassurance without fear is to have belief without grace - temporary faith;xxii and to have fear without reassurance is to doubt the divine, the sin which condemned Judas for eternity. In this sense the interlinking of fleshy and heavenly desires which can be traced in Rolfe's letter do indeed make it a classic of its type. But the powerlessness of the Christian to alter their eternal fate which motivates Rolfe's self-analysis raises important questions about the issue of conversion itself. As Reformed thought proposed that the individual was either saved or reprobate by an act of God who could foresee everything, 'to the very minutest, even to a sparrow' as Calvin put it, then the work of the convertor was given limits. How could a mere human convert when the work of salvation was God's alone? This important question can be answered through a close reading of baptismal theology and through an analysis of the writings surrounding the conversion of Pocahontas, and once again the issue of desire emerges to clarify the theological argument.

IV

At the beginning of the nineteenth century John Davis retold the life of Pocahontas to an American readership and argued that through her baptism she had been 'granted the gift of eternal life.'xxiv Such an interpretation seems at odds with the theology of the settlers, but it also follows, it would seem, the presentation of baptism in the work of Martin Luther. Luther wrote, $[\mathrm{w}]$ henever we hear the word and are baptised, there 
we enter into eternal life.' The implications of this, Karl Barth argued, seem to be that 'a small child becomes a Christian in baptism'.xxv Baptism becomes problematically tied up with salvation which is, for Luther and Reformed thinkers, the act of God alone. In the providential order of the Reformed world it was not for humans to save themselves but for the divine; it was not for the individual Christian to seek for grace but for that grace to be given by God.

For Luther, whose baptismal theology was most influential in English thought,xxvi baptism was a key representation of the work of God. In opposition to the condemnation of outward signs of worship (found in the Elizabethan vestiarian controversy, for examplexxvii), Luther proposed that baptism was 'an appointed place for mankind's encounter with the divine' (24), it was not made by man.xxviii Baptism was a symbol of humanity's salvation which could only work if faith (and therefore grace) had been conferred before the baptism took place otherwise the implications were that faith was a product of baptism (and therefore humanity) itself. To use Jonathan D. Trigg's formulation, Luther proposed not that baptism produced faith but that baptism 'adorns the baptised with holiness; with righteousness; and even with wisdom.' (76) The faith of the infant (fides infantium) or, more importantly here, the convertee, represents the always-alreadiness of faith in the saved human.

In the discussions of conversions which appeared in sermons and in print in the late sixteenth and early seventeenth century what is emphasised is the sense of lost and found. The convertee was never without grace (an impossibility if they were always-already saved) but had merely left the path offered by grace. The anonymous author of $A$ True and Sincere declaration of the purpose and ends of the Plantation begun in Virginia argues that 'The Principall and Maine Ends ... weare first to preach, \& baptize into Christian Religion, and by propagation of that Gospell, to recouer out of the armes of the Diuell, a number of poore and miserable soules'.xxix This is recovery and not creation, two very different things.

Similarly at his baptism in London in April 1577 Nathaniel the Jew confessed that he was 'heartilie sorie for my so long going astraye from the faith of this man Jesus after the evill teaching of my countrie men and kinsmen after the flesh'.xxx Other early modern convertees present parallel pictures of their journey to the 'truth': William Tedder a seminary priest recanted his Roman faith in 1588 stating that it hath pleased God to call 
me backe againe'. xxxi Pocahontas left no such confession of faith but the logic of Reformed belief would make her conversion no different. The baptism does not provide her with an entry into the Christian faith, that was already in place, what it does is enact the entry. Faith, as Trigg argues, is given by God, and is always present, not in its fully fledged state, but as a divine possibility and creation in man, as opposed to a natural human possibility or work.' (106)

But even while Reformed thought emphasised predestination the sense of the incomplete nature of faith underlines the importance of the missionary endeavour. While the settlers may not be making Christians they were still performing a vital function which can be traced to the Reformed theory of double-justification. This proposed that the initial and vital justification of the Christian came from God alone in the form of grace and was unknowable, but the second justification - termed regeneration or sanctification - was both necessary and knowable, apparent in the moral actions of the Christian. xxxii Good works could be performed in order to prove salvation rather than achieve it. Alexander Whitaker offered a reason for this belief. Writing a year before performing Pocahontas' baptism he stated

if God should presently reward good works, who then would not be a prodigall giuer, who then would bee a faithfull giuer? For when a man is certaine of present gaine he will not spare to giue abundantly, because he seeth an exceeding profit ready to be put into his hands for so doing: and this would stirre vp the most couetous wretch in the world to be liberall, gaping out of meere couetousnesse, after an ouer-plus of reward. Wherefore God hath made the time and condition of his rewards doubtfull, that we might not bee couetous of the benefit: but that he might exercise our faith, and teach vs with patience of hope to expect the appointed time of his reward. (29)

Where faith is divine all other routes - education, good works - are purely human means of achieving salvation. Alone they mean nothing, they represent the Pelagian position, but with faith they can mean everything. Whitaker wrote 'no work of any man can please God, before the man himselfe bee approued of him, and then all our good deeds shall be accepted of him.' (11) 
The missionary endeavour enacted this belief. For the English settlers the conversion of the natives meant not only the sanctification of the otherwise unregenerate, it also proved that the settlers themselves were truly saved. William Crashaw put this in the negative: writing of the natives he stated 'being themselues vnconuerted [they] haue therefore no care to conuert others.' $\left(\mathrm{C} 2^{\mathrm{r}}\right)$ By implication to desire to convert, to work for the salvation of others, as John Rolfe had already discovered, was the role of the always-already saved. Conversion brings assurance not only to the convertee but also to the converter. The emphasis once again upon the issue of desire here is important. Desire is needed not only to place faith under question and prove its existence, but to produce complete faith in the first place. For Reformed thinkers such as William Perkins desire was something which lay at the heart of the notion of regeneration.

\section{$\mathrm{V}$}

The role of the parent in educating the child is well documented in early modern society. xxxii Perkins proposed that they should have their child baptised and give it a name and that they should endeauour to sowe the seedes of godlinesse and religion in the heart of the child, so soone as it comes to the vse of reason and vnderstanding'. (III, 694) Similarly, in their reading of the fifth commandment, John Dod and Robert Cleaver emphasised the role of education:

The parents dutie to the children in their tender yeares and childhood, is first to instruct them in religion, to season them with the words of pietie, or by little and little to drop in the grounds of holiness into them, even so soone as they are able to speake and beginne to haue the least vse of vnderstanding. xxxiv

While the question of the capacity of the infant to learn was not an issue in the baptism of Pocahontas a similar sense of parental duty was exercised by the men concerned with her education: Rolfe himself, Sir Thomas Dale and Alexander Whitaker.

Baptism, however, had a particular impact on the issue of duty to the child or convertee. William Coster's formulation that 'baptism was a second birth, the priest a spiritual midwife, and the profane, natural parents replaced with spiritual ones' is a useful one.xxxv Pocahontas was removed, literally and spiritually, from her birth parents and was 'returned' to her 
true father, Christ. As Captain John Smith who was famously 'rescued' from execution by Pocahontas noted, 'shee never had desire to goe to her Father, nor could well endure the society of her owne nation.'xxxvi Pocahontas' removal from her blood family which began with her capture by Captain Argall was maintained by choice because she had been educated to make the correct choice.

The education which convertees, like newly baptised children, underwent had a specific form in England. Limited by the high rates of illiteracy, ${ }^{x x x v i i}$ preachers relied on the catechism, a massive number of which were published in the late sixteenth and early seventeenth century. xxxvii Their popularity reveals the importance of achieving a true understanding of Christian ideas without the need for, or possibility of, literacy. Henry Holland defined catechising as a forme of instruction, wherein the same matter is often repeated that the weake may the better conceiue it, and remember it.' (Aiiv). In The Foundation of the Christian Religion Gathered into Six Principles Perkins presented a collection of beliefs to be learned by ' $A L L$ IGNORANT PEOPLE that desire to be instructed'. (I, A2 r). The ignorant person would learn by heart six basic ideas. The 'second principle' is a useful illustration here of the catechitical method:

Q. What doest thou beleeue concerning man, and concerning thine own self?

A. All men are wholly corrupted with sin through Adams fall, and so are become slaues of Satan, and guilty of eternall damnation. (I, 1)

The exposition, or more complex reading of this principle, spells out the Reformed idea of the status of humanity even more clearly:

Q. Let vs now come to our selues, and first tell mee what is the naturall estate of man?

A. Euery man is by nature dead in sin as a loahtsome [sic] carrion, or as a dead corps lieth rotting and stinking in the graue, hauing in him the seed of all sinnes. (I, 3-4)

The repetition of this understanding of humanity which is called for in Perkins' catechism works to fulfill, through the words themselves, the Reformed sense that human power and immortality are found, paradoxically, through the acknowledgement of human powerlessness. In 
this way Reformed thinkers present learning as part of the process of regeneration. The catechism offers the child the education which is promised in baptism, and it teaches a clearly Reformed line on the status of the individual Christian. William Hubbocke proposed that the infant cannot reason, yet it hath the seed of reason'; it is the process of education which will - to extend the metaphor - water this seed.xxxix Humans are, Reformed beliefs argue, utterly destitute but utterly able to learn. Salvation does not cancel out sinfulness, God's mercy is all the greater because of the undeserving nature of humanity. We are saved even though we are damned. ${ }^{\mathrm{xl}}$

Because of the sinfulness which is in the heart of all Christians learning is vital; even the illiterate must have access to the truths of the Bible. Repetition, however - what is called for in catechisms - may seem to be very different from understanding, and in this age of printing and increased emphasis on the interpretation of the scripture the problem of the status of the illiterate emerges. Perkins' emphasis on the desire for instruction is one way of dealing with this issue: the ignorant believer is a true believer in their will to learn. It is implicit that such a will is God-given, and therefore in itself proof of regeneration and ultimately salvation. Will is, in fact, to be found in the operation of conscience.

In the case of Pocahontas her baptism brought with it a new name Rebecca - and new learning. Captain John Smith relates her education in a letter to Queen Anne in 1617 noting 'how carefull they were to instruct her in Christianity, and how capable and desirous shee was thereof, after she had beene some time thus tutored'. (II, 251) Sir Thomas Dale, one of her tutors, records in his letter 'To the R.'

Powhatans daughter I caused to be carefully instructed in Christian Religion, who after shee had made some good progresse therein, renounced publickly her countrey Idolatry, openly confessed her Christian faith, was, as she desired, baptised, and is since married to an English Gentleman of good understanding ... (55)

Their words are wisely chosen: the renunciation of her native idolatry and confession of faith are a return to the true and original belief. This belief is always-already evidenced through Pocahontas' desire for instruction and baptism -symbolic entry into the faith. Even her fleshy desire, her choice of 
husband, reveals her salvation. Rolfe is presented as a man of good understanding; that is, a man with a fully functioning conscience. Like Smith's and Dale's words Pocahontas' love is wisely chosen and her wise choice proves her salvation. Flesh and spirit, desire and understanding are linked in the Reformed interpretation of baptism, regeneration and conscience.

The story of Pocahontas' baptism and the material which surrounds it - the sermons, religious tracts, personal letters, legal statutes - all reveal the paradoxes which ultimately support the operation of a coherent and often terrifying theology. There is nothing the individual can do and there are actions which the individual must undertake; there is the devilishly inspired logic and the God-given understanding; there is flesh and there is spirit; there is the repudiation of desire and the necessity of longing; but ultimately there is the sense of salvation despite, or rather because of, the existence of temptation. Pocahontas' baptism is an image of the workings of Reformed faith. Fleshy desire is at once denied, produced and necessary just as predestination underlines God's absolute power but also emphasises the necessity of human action. It is John Rolfe's denial of his 'unbridled desire of carnall affection' that the workings of salvation can be sought.

\section{NOTES}

i. Throughout this essay I follow Alister E. McGrath's definition of the term 'Reformed' as referring to broadly Calvinist ideas. See McGrath, Reformation Thought: An Introduction, second edition (Oxford: Blackwell, 1993), 8. For the reasons outlined by Christopher Durston and Jacqueline Eales I avoid the term 'puritan' throughout the rest of this article. See Durston and Eales, 'Introduction: The Puritan Ethos, 1560-1700', in Durston and Eales ed., The Culture of English Puritanism, 1560-1700 (Basingstoke: Macmillan, 1996), especially 1-6. I am grateful to Tracey Hill for her comments and suggestions on an earlier draft of this essay.

ii . 'Letter of John Rolfe, 1614', reproduced in Lyon Gardiner Tyler ed., Narratives of Early Virginia 1606-1625 (New York: Barnes \& Noble, 1946), 240. All further references to this edition are given in the text.

iii. Peter Hulme, Colonial Encounters: Europe and the Native Carribean, 1492-1797 (London: Methuen, 1986), 144.

iv. John Calvin, Institutes of the Christian Religion (1559 edition), translated by Henry Beveridge (London: James Clarke \& Co, 1949), Volume I, 181. All 
further references to this edition are given in the text.

v. Calvin is here invoking Matthew 10.29: 'Are not two sparrows sold for a farthing? and one of them shall not fall on the ground without your Father.'

vi. [Thomas Morton], A Treatise of the threefolde state of man (1596), 5-6.

vii. I am not concerned with the historical debate about the primacy of religious belief in the establishment of the Virginia Colony here, but an important interpretation which argues for the importance of religion in the establishment of the colony can be found in John Parker, 'Religion and the Virginia Colony 1609-10', in K.R. Andrews, N.P. Canny and P.E.H. Hair ed., The Westward Enterprise: English Activities in Ireland, the Atlantic and America 1480-1650 (Liverpool: Liverpool University Press, 1978), 245-70. For alternative arguments which emphasise the importance of commerce see Wesley Frank Craven, Dissolution of the Virginia Company: The Failure of the Colonial Experiment (New York: Oxford University Press, 1932), especially 24; and T.H. Breen, Puritans and Adventurers: Change and Persistence in Early America (Oxford: Oxford University Press, 1980), especially 106-26.

viii . Augustine, The City of God, translated by Henry Bettenson (Harmondsworth: Penguin, 1972), 157.

ix. Alexander Whitaker, Good Newes from Virginia (1613), B ${ }^{\mathrm{v}}$. All further references to this edition are given in the text.

x. Alister E. McGrath provides a useful glossary of terms in which Pelagianism is defined as 'An understanding of how humans are able to merit their salvation which is diametrically opposed to that of Augustine of Hippo and places considerable emphasis upon the role of human works and plays down the idea of divine grace.' Augustinian ideas are defined as 'concerning the doctrine of salvation, in which the need for divine grace is stressed.' McGrath, Reformation Thought, 240 and 237.

xi. Ralph Houlbrooke, 'The Puritan Death-bed, c.1560-c.1660', in Durston and Eales ed., The Culture of English Puritanism, 124.

xii. William Perkins, The Foundation of the Christian Religion Gathered into Six Principles (1591), in The Workes of That Famous and Worthy Minister of Christ in the Vniuersitie of Cambridge, Mr William Perkins (1616-18), Volume I (1616), 1. All further references to this edition are given in the text.

xiii. Arthur Dent, The Plaine Mans Path-way to Heaven (1601). Christopher Hill notes that this text went through 25 editions between 1601 and 1640 . Hill, Society and Puritanism in Pre-Revolutionary England (1964), (Reprinted, Harmondsworth: Penguin, 1986), 433. 
xiv. John Moore, A Mappe of Mans Mortalitie (1617), 14.

xv. William Crashaw, A Sermon Preached in London before the right honorable the Lord LA WARRE, Lord Gouernour and Captaine Generall of Virginia (1610), $\mathrm{A} 4^{\mathrm{v}}-\mathrm{B}^{\mathrm{r}}$. All further references to this edition are given in the text.

xvi. H.C. Porter, Reformation and Reaction in Tudor Cambridge (Cambridge: Cambridge University Press, 1958), 312. Antinomianism is the heretical belief that those elected to salvation have no obligation to obey the moral law.' Margo Todd, 'Glossary', in Todd ed., Reformation to Revolution: Politics and Religion in Early Modern England (London: Routledge, 1995), 272.

xvii. William Symonds, Virginia: A Sermon Preached at White-Chappel, In the presence of many, Honourable and Worshipfull, the Adventurers and Planters for VIRGINIA (1609), 35.

xviii. In this I agree with Peter Hulme who notes that Rolfe's 'doubts clearly centre on miscegenation', but am arguing that Rolfe's emphasis on both conversion and the convertability of Pocahontas undercut these doubts. Hulme, Colonial Encounters, 144.

xix. Raphe Hamor, A True Discourse of the Present Estate of Virginia (1615), 10. All further references to this edition are given in the text.

xx. Stevie Davies, 'Introduction', to Davies ed., Renaissance Views of Man (Manchester: Manchester University Press, 1978), 15.

xxi. Sir Philip Sidney, Astrophil and Stella (1591), 1, line 14 in Katherine Duncan-Jones ed., Sir Philip Sidney: Selected Poems (Oxford: Clarendon, 1988), 117. On the similar issue of erected wit and infected will in The Defence of Poetry (1579) Alan Sinfield argues that Sidney's position is between 'two stools of protestant thought', Calvin's and Hooker's. Sinfield, 'The Cultural Politics of the Defence of Poetry', in Gary F. Waller and Michael D. Moore ed., Sir Philip Sidney and The Reinterpretation of Renaissance Culture (London: Croom Helm, 1984), 135-6.

xxii. See R.T. Kendall, Calvin and English Calvinism to 1649 (Oxford: Oxford University Press, 1979), 9.

xxiii. Temporary faith is a faith which even the reprobate might have, which looks to all intents and purposes like justifying faith but does not lead to salvation. Henry Holland defines it as the ability to professe the Gospell but without sense of the power of it, or loue or liking to it, this faith may proceed yet to a great reioycing and to some heuenly fruite, and yet is it but false and temporarie.' Holland, The Historie of Adam, or the foure-fold state of Man (1606), Hhiiiv. All further references to this edition are given in the text. How 
to tell the difference between justifying faith and temporary faith was a problem which exercised Reformed thinkers. On the issue of the problem of double-predestination, see John Stachniewski, The Persecutory Imagination: English Puritanism and the Literature of Religious Despair (Oxford: Clarendon, 1991).

xxiv. John Davis cited in Robert S. Tilton, Pocahontas: The Evolution of an American Narrative (Cambridge: Cambridge University Press, 1994), p.120. For more recent biographies see Grace Steele Woodward, Pocahontas (Norman: University of Oklahoma Press, 1969), 71 and Philip L. Barbour, Pocahontas and her World (London: Robert Hale \& Company, 1971), 24.

xxv. Luther, Luther's Works, 5, 247; and Barth, Church Dogmatics, 169, cited in Jonathan D. Trigg, Baptism in the Theology of Martin Luther (Leiden: E.J. Brill, 1994), 20 and 3. I am indebted to Trigg's account in the following paragraphs and in-text references in the discussion of baptismal theology are from his study. For the ideas of other Reformed thinkers see McGrath, Reformation Thought, 170-85.

xxvi. On the importance of Luther see G.W. Bromiley, Baptism and the Anglican Reformers (London: Lutterworth Press, 1953), 3. The important differences between Lutheran and Calvinist interpretations of baptism are outlined in Bodo Nischan, 'The Exorcism Controversy and Baptism in the Late Reformation', The Sixteenth Century Journal, 18:1 (1987), 31-51. See also G.R. Evans, 'Calvin on signs: an Augustinian dilemma', Renaissance Studies, 3:1 (1989), 38.

xxvii. On the vestiarian controversy, see M.M. Knappen, Tudor Puritanism: A Chapter in the History of Idealism (1939), (Reprinted, London: Chicago University Press, 1970), 187-216.

xxviii. It is the lack of scriptural authority - 'appointed place' - which caused the reduction in the number of sacraments in the Reformed church from the Catholic seven (baptism, the eucharist, penance, confirmation, marriage, ordination, and extreme unction) to just two (baptism and the eucharist). See McGrath, Reformation Thought, 159-87.

xxix. Anon., A Trve and Sincere declaration of the purpose and ends of the Plantation begun in Virginia (1610), 2.

xxx. Nathaniel, 'The confession of faith', contained in John Foxe, A Sermon Preached at the Christening of a Iewe, at London (1578), n.p.

xxxi. The Recantation made at Paules Crosse, by William Tedder Seminarie Priest, the first of December, Anno. 1588 (1588), 7. 
xxxii. The ideas emerge in Calvin's thought, but are first given the clear theological designation 'double justification' in the ideas of Martin Bucer. See McGrath, Reformation Thought, 111-12.

xxxiii. See, for example, John Morgan, Godly Learning: Puritan Attitudes Towards Reason, Learning and Education, 1560-1640 (Cambridge: Cambridge University Press, 1986). On attitudes to learning in the colonies of the New World see Philip Greven, The Protestant Temperament: Patterns of Child Rearing, Religious Experience and The Self in Early America (New York: Meridian, 1979).

xxxiv. John Dod and Robert Cleaver, A Treatise or Exposition Vpon the Ten Commandments (1603), $7^{\mathrm{r}}$.

xxxv. William Coster, "From Fire and Water": The Responsibilities of Godparents in Early Modern England', in Diana Wood ed., The Church and Childhood (Oxford: Blackwell, 1994), 305.

xxxvi. Captain John Smith, The Generall Historie of Virginia, New England, and the Summer Isles (1624), in Philip L. Barbour ed., The Complete Works of John Smith (1580-1631) in Three Volumes (Chapel Hill: University of North Carolina Press, 1986), II, 251. All further references to this edition are given in the text.

xxxvii. Even in $164270 \%$ of adult men were illiterate. Figure from Keith Wrightson, English Society 1580-1680 (London: Unwin Hyman, 1982), 190.

xxxviii . See Ian Green, "For Children in Yeeres and Children in Understanding": The Emergence of the English Catechism under Elizabeth and the Early Stuarts', The Journal of Ecclesiastical History, 37:3 (1986), 397-425. Green states that 'over 350 different catechitical forms or works can be traced, the vast majority of which, it should be added, were of English origin and were published after 1570' (400).

xxxix. W.H. [William Hubbocke], An Apologie of Infants in a Sermon (1595), 24.

$\mathrm{xl}$. As R.T. Kendall notes 'all the reprobate are born into the state of damnation, not all who are born into the state of damnation are reprobate.' Kendall, Calvin and English Calvinism, 4, footnote 3. 